\title{
Effect of Percutaneous Electric Stimulation with High Frequency Alternating Currents on the Sensory-Motor System of Healthy Volunteers
}

\author{
David Martín-Caro Álvarez \\ Universidad de Castilla-La Mancha \\ Diego Serrano-Muñoz ( $\nabla$ diego.serrano@uclm.es ) \\ Universidad de Castilla-La Mancha \\ Juan José Fernández-Pérez \\ Universidad de Castilla-La Mancha \\ Julio Gómez-Soriano \\ Universidad de Castilla-La Mancha \\ Juan Avendaño-Coy \\ Universidad de Castilla-La Mancha
}

\section{Research Article}

Keywords: Nerve block, High-Frequency, Percutaneous Electric stimulation, Peripheral nerve.

Posted Date: January 14th, 2022

DOI: https://doi.org/10.21203/rs.3.rs-1253292/v1

License: (c) (i) This work is licensed under a Creative Commons Attribution 4.0 International License. Read Full License 


\section{Abstract}

\section{Background}

Former studies investigated the application, both transcutaneous and with implanted electrodes, of high frequency alternating currents (HFAC) in humans for blocking the peripheral nervous system. The present trial aimed to assess the effect of HFAC on motor response, somatosensory thresholds, and peripheral nerve conduction, when applied percutaneously with ultrasound-guided needles at frequencies of $10 \mathrm{kHz}$ and $20 \mathrm{kHz}$ in healthy volunteers.

\section{Methods}

A parallel, placebo-controlled, double-blind, randomized clinical trial was conducted. Ultrasound-guided HFAC at $10 \mathrm{kHz}$ and $20 \mathrm{kHz}$ and sham stimulation were delivered to the median nerve of 60 healthy volunteers ( $n=20$ per group) for 20 minutes. The main assessed variables were maximum isometric flexion strength (MFFS) of the index finger, myotonometry, pressure pain threshold (PPT), mechanical detection threshold (MDT), and antidromic sensory nerve action potential (SNAP). Measurements were recorded pre-intervention, during the intervention 15 minutes after its commencement, immediately post-intervention, and at 15 minutes post-intervention.

\section{Results}

A decrease in the MFFS was observed immediately post-intervention compared to baseline, both in the $10 \mathrm{kHz}$ group [-8.5 \%; $95 \%$ confidence interval $(\mathrm{Cl})-14.9$ to -2.1$]$ and the $20 \mathrm{kHz}$ group $(-12.0 \% ; 95 \% \mathrm{Cl}-18.3$ to -5.6$)$. At 15 minutes post-intervention, the decrease in the MFFS was $-9.5 \%(95 \% \mathrm{Cl}-17.3$ to -1.8$)$ and $-11.5 \%(95 \% \mathrm{Cl}-9.3$ to -3.8$)$ in the 10 $\mathrm{kHz}$ and $20 \mathrm{kHz}$ groups, respectively. No changes over time were found in the sham group. The between-group comparison of changes in MFFS showed a greater reduction of $-10.8 \%(95 \% \mathrm{Cl}-19.8$ to -1.8$)$ immediately postintervention in the $20 \mathrm{kHz}$ compared to the sham stimulation group. Muscle tone increased over time in both the $10 \mathrm{kHz}$ and $20 \mathrm{kHz}$ groups, but not in the sham group. The intergroup comparison of myotonometry showed a superior effect in the $20 \mathrm{kHz}(6.7 \%, 95 \% \mathrm{Cl} 0.5$ to 12.9) versus the sham group. No significant changes were observed in the rest of the assessed variables.

\section{Conclusions}

The ultrasound-guided percutaneous stimulation applying $10 \mathrm{kHz}$ and $20 \mathrm{kHz}$ HFAC to the median nerve produced reversible reductions in strength and increases in muscle tone with no adverse effects.

\section{Background}

Preclinical studies in animals have shown that high-frequency alternating currents (HFAC) stimulation $>1 \mathrm{kHz}$ blocked the peripheral nerve system, which quickly reverted without damaging the nerve [1-6].

To date, there is no agreement about the optimal frequency to block nerve conduction in humans. A systematic review by Avendaño et al. [7] about HFAC reported a wide range of frequencies (4 $\mathrm{kHz}$ to $30 \mathrm{kHz}$ ) that could attain nerve block in animals via implanted electrodes. The minimum frequency to reach nerve block depends on the axon type and nerve width. However, the minimum frequency for currents delivered via implanted electrodes to the median nerve in primates, whose diameter is similar to that of humans, was $20 \mathrm{kHz}$ for the complete nerve block [4].

Clinical trials applying transcutaneous HFAC to the peripheral nervous system showed that $5 \mathrm{kHz}$ currents increased somatosensory thresholds, such as mechanical pain, thermal pain, and tactile sensitivity [8-9], and decreased voluntary strength $[10,9]$. The application of $10 \mathrm{kHz}$ HFAC also showed the immediate inhibition of motor response and sensory 
perception [9] that can persist up to 10 minutes after the stimulation [10-11]. A decrease in voluntary strength has also been observed during the transcutaneous application of $20 \mathrm{kHz}$ HFAC [12].

The main limitation of transcutaneous current application is the distance between the electrode and the nerve. Bhadra et al. [2] observed that the longer the distance from electrode to nerve the greater the intensity required to reach nerve block. Ackermann et al. [13] determined that the optimal distance between the electrode and nerve was 1-2 mm, which is not possible during transcutaneous current application. No research has been found about percutaneous HFAC stimulation with needles in humans, but studies have been conducted with implanted intrafascicular electrodes placing ring-electrodes around the nerve [14-17]. Percutaneous application using needles could allow for reducing the distance between electrode and nerve [18], and therefore decrease the current intensity required to reach nerve block. Additionally, percutaneous stimulation can avoid the inconveniences associated with the surgical implantation of electrodes, such as scars or additional procedures to replace them [19]. This intervention has been shown to be safe and with minimum risks in low- [20] and high-frequency [21] electrical stimulations.

The main aim of this trial was to assess the effect of percutaneous electric stimulation with $10 \mathrm{kHz}$ and $20 \mathrm{kHz} \mathrm{HFAC}$ applied to the median nerve compared to sham stimulation on motor response, somatosensory thresholds, and peripheral nerve conduction. The secondary objectives were to evaluate adverse effects, proximal and distal temperatures at the stimulation area, the subjective perceptions of the participants during the intervention, and blinding success.

\section{Methods}

\section{A. Design}

A parallel randomized clinical trial was conducted with a double-blind placebo control. Sixty healthy subjects volunteered to participate. All participants provided written informed consent, which had been approved by the relevant local ethics committee (Ref: 441;11/11/2019). The study was formerly registered at ClinicalTrials.gov (NCT04346719). Epidat 3.1 software was employed for the simple balanced randomization of the sample. Subjects were randomly assigned to the three intervention groups (10 kHz HFAC, $20 \mathrm{kHz}$ HFAC, and sham stimulation) by an independent investigator. Both participants and assessors were blinded to the group assignment, which was kept in a closed envelope throughout the intervention so that only the researcher who delivered the intervention was aware of group allocations. The intervention lasted 20 minutes. Variables were measured at four time points: i) pre-intervention ( 0 min), ii) during the intervention, 15 minutes following the start of the stimulation (15 min), iii) immediately post-intervention (20 $\mathrm{min}$ ), and iv) 15 minutes after the finalization of the intervention (35 min) [8]. However, both the antidromic sensitive action potential (SNAP) and maximal flexion finger strength (MFFS) were not recorded during the intervention because of interferences with the application of electric currents and the discomfort needles cause during muscle contractions, respectively.

\section{B. Subjects}

Healthy volunteers were recruited, 18 to 40 years of age, with no pathologies of the nervous system, and with no allergy to nickel or intolerance to the percutaneous application of electric currents. The criteria for exclusion were: surgical procedure or osteosynthesis material in the upper limb where the electric stimulation is to be applied, epilepsy, fear of needles, infectious disease, neuro-muscle disease, heart failure, diabetes, cancer, pacemaker or other implanted electric devices, pregnancy, tattoo or skin condition in the area not allowing for the delivery of the intervention, and use of substances or medication (e.g. anticlotting, thrombolytic, analgesic, corticoid, antidepressant, antiepileptic) during the trial and in the seven days before their participation. 


\section{Intervention}

The duration of both active HFAC and sham stimulation was 20 minutes. The interventions were delivered to the nondominant arm with the participants in the supine position. Antiseptic and skin disinfection treatment with $2 \%$

chlorhexidine in an alcohol base was applied on the intervention area. A Samsung HS50 (Samsung healthcare; Seoul, South Korea) ultrasound device was employed for the percutaneous guided application of currents with a lineal probe of $12 \mathrm{mHz}$. A short-axis approach to the median nerve was performed on the anterior aspect of the middle third of the forearm placing two $0.30 \mathrm{~mm}$ x $40 \mathrm{~mm}$ acupuncture needles (Agupunt $\AA$; Barcelona, Spain) close to the epineurium of the median nerve $(1 \mathrm{~mm})$, one needle on each side of the nerve. The average depth of the needle introduced into the tissue was $3 \mathrm{~cm}$ (Figure 1).

A Myomed 932 (Enraf-Nonius; Delft, The Netherlands) device connected to the needles by a clamp applied the current in the three interventions. All interventions were delivered in a university laboratory facility under reduced noise and temperature $\left(21^{\circ} \mathrm{C}-25^{\circ} \mathrm{C}\right)$ conditions.

\section{$\underline{10 \mathrm{kHz} \text { and } 20 \mathrm{kHz} \text { current stimulation }}$}

High frequency alternating currents (HFAC) with sinusoidal waveform were applied at a frequency of either $10 \mathrm{kHz}$ or $20 \mathrm{kHz}$ in the active intervention groups. The intensity progressively increased until producing a feeling of "strong but comfortable" tingling, just under the motor threshold [22]. Subsequently, the intensity was increased until a minimal visible contraction was observed and then slightly lowered below the motor threshold. Due to the accommodation to the stimulus, the intensity was adjusted every two minutes to rise it if the participant's perception of the current decreased [23].

\section{Sham stimulation}

Sham stimulation was applied with the same device and needle placement. The same parameters were used as in the $10 \mathrm{kHz}$ intervention except for the current intensity, which was initially adjusted up to the sensitive threshold and, once the participant perceived a tingling sensation for a few seconds, the intensity was gradually lowered to and maintained at $0 \mathrm{~mA}$ for the entire session.

\section{Outcome Measurements}

\section{Maximum isometric finger flexion strength and myotonometry}

The main outcome measurements related to motor activity were the MFFS of the index finger and mechanical characteristics of the opponens pollicis muscle as assessed through myotonometry. MFFS of the index finger was evaluated with the participant in the supine position and their hand in pronation pressing on a MicroFet 2TM digital hand dynamometer (Hoggan Scientific, LLC; Utah, USA), a device with proven intra- and inter-assessor reliability [24]. The MFFS was calculated as the mean of three measurements in kgs that were taken with a contraction time of 3 seconds and a rest of 5 seconds between measurements [25].

A myotonometer (Myoton AS; Tallinn, Estonia) was used to evaluate the mechanical properties of the muscle. Ten mechanical stimuli of $0.4 \mathrm{~N}$ force and $0.15 \mathrm{~ms}$ duration were applied to the opponens pollicis muscle of the limb where the intervention was performed with one-second intervals between stimuli. If the variation coefficient exceeded $3 \%$, the measurement was repeated. Stiffness $(\mathrm{N} / \mathrm{m})$, frequency $(\mathrm{Hz})$, and logarithmic decrement (expressed in arbitrary units) were the collected variables. Stiffness measures the force that results in tissue shape changes. The frequency of damped oscillations serves to measure the resistance of the tissue to mechanical stress and is considered to be an 
indirect measure of muscle tone. The decrement serves to characterize tissue elasticity by measuring the loss of mechanical energy as the amplitude of the oscillations decreases [26-27].

\section{Mechanical detection threshold and pressure pain threshold}

Somatic sensitivity was evaluated by means of the mechanical detection threshold (MDT) and pressure pain threshold (PPT). The MDT was measured via modified Von Frey filaments (OptiHair2, MARSTOCKnervtest; Marburg, Germany) on the palmar aspect of the hand in an area of $1 \mathrm{~cm}^{2}$ proximal to the head of the second metacarpal and on the thenar eminence. Filaments with a diameter of $0.4 \mathrm{~mm}$ delivered forces of $0.25,0.5,1,2,4,8,16,32,64,128,256$, and $512 \mathrm{mN}$ [28]. Seven stimuli were applied and the threshold was determined when at least four were perceived with a filament [29].

The PPT was recorded on the palmar aspect of the trapeziometacarpal joint via a digital algometer with an increment scale of $0.1 \mathrm{~N}$ (Wagner Instruments, model FDIX; Greenwich, USA) and a circular applicator of $1 \mathrm{~cm}$ in diameter. The pressure was increased at an approximate rate of $5 \mathrm{~N} / \mathrm{s}$ [30]. Three measurements were taken with an interval of 10 seconds between them [31] and the PPT $(N)$ was obtained from the average of the three measurements [32-34].

\section{Antidromic sensory nerve action potential (SNAP).}

The SNAP of the median nerve was recorded for assessing the effect on peripheral nerve conduction [35]. Nerve stimulation was performed on the inner side of the arm using a transcutaneous bipolar electrode, with a fixed distance between electrodes of $1 \mathrm{~cm}$ and placing the cathode $40 \mathrm{~cm}$ from the recording electrode. Two ring electrodes on the index finger were employed to record the potential, with the ground electrode placed on the radial side of the wrist joint [36-37]. A constant-current stimulator (Digitimer LTD, model DS7A; Letchworth Garden, United Kingdom), an analogic/digital data acquisition card (Cambridge Electronic Devices; Cambridge, United Kingdom), and an amplifier (ETH-256 iWorxs; Dover, USA) with a $3 \mathrm{~Hz}$ high-pass filter and a $2000 \mathrm{~Hz}$ low-pass filter and an amplification of 1 were employed for the stimulation and recording. Supramaximal stimuli were applied with a pulse width of $1000 \mu \mathrm{s}$ and a frequency of $1 \mathrm{~Hz}$. The latency and amplitude of the SNAP were calculated as the mean value of ten measurements. At baseline, two SNAPs were recorded with a 2-minute interval to analyze the power stability, and the average was used as the basal SNAP value.

\section{Temperature of forearm and arm}

A temperature monitor (model DRT4, Moor Instruments brand; Devon, United Kingdom) was employed to record temperature. One recording sensor was applied distal to the procedure, on the palmar side of the head of the first metacarpal, and another sensor proximal to the procedure, on the anterior side of the forearm [8]. The room ambient temperature was also recorded.

\section{Adverse effects and subjective perception}

For the evaluation of adverse effects and the subjective perception of the participants, a standardized questionnaire was designed and completed at the end of the intervention. The questionnaire included nine items with "Yes/No" response options to evaluate pain, swelling, heat, redness, coldness, numbness, loss of strength, heaviness, and tingling in the hand and the intervention area. The unpleasantness and pain feeling perceived during the intervention were also assessed using a numerical scale from 0 to 10, where 0 corresponded to "not at all" and 10 to "the maximum possible". Additionally, participants were asked to report whether they perceived any of the above-mentioned effects or sensations in the intervention area in the days following the intervention. 
The blinding success of the participants and the evaluator was assessed after the intervention ended [38]. For this purpose, they were asked "What type of treatment do you believe you or the participant have received?", with five response options: (1) "I strongly believe that I have received an experimental treatment"; (2) "I somewhat believe that I have received an experimental treatment"; (3) "I strongly believe that I have received a placebo"; (4) "I somewhat believe that I have received a placebo"; (5) "Do not know, no answer".

\section{E. Statistical Analysis}

The sample size was calculated based on a previous pilot test carried out on seven healthy volunteers [21]. For an expected between-group mean difference (MD) in the PPT of $10.3 \mathrm{~N} / \mathrm{cm}^{2}$, with a standard deviation (SD) of 11.3 $\mathrm{N} / \mathrm{cm}^{2}$ in the experimental group and SD $9.9 \mathrm{~N} / \mathrm{cm}^{2}$ in the control group, and considering a type I error (a) of 0.05 and a power of $80 \%$, the sample size was estimated to be 17 subjects per group $(n=17)$. To compensate for possible dropouts, a supplementary $17 \%$ was added to the sample finally yielding a total of $n=20$ participants per group.

For the comparison of basal characteristics between groups, a descriptive analysis and inferential statistics for basal demographic variables were performed for independent groups (parametric or non-parametric depending on the variable). A two-factor (intervention-time) repeated-measures analysis of variance (ANOVA) with a Bonferroni post-hoc correction was conducted for the following outcome variables: MFFS, myotonometry, PPT, temperature, and SNAP. For those variables violating sphericity, the Greenhouse-Geisser correction was employed. Additionally, changes in the above-mentioned variables over time were calculated and an intergroup comparison was performed via a one-factor (intervention) analysis of variance (ANOVA) with a Bonferroni post-hoc correction. The Friedman test was employed for assessing the MDT with a post-hoc analysis via the Tukey's test for intragroup comparison. The Kruskal-Wallis test was used for the comparison of MDTs between interventions.

The Chi-squared test was used for the analysis of adverse effects. Unpleasantness and pain during the intervention were evaluated by means of a one-factor (intervention) ANOVA with a Bonferroni post-hoc correction. All outcome variables were normalized in percentages with respect to basal values prior to the analyses and statistical significance was set at $p<0.05$. The IBM SPSS Statistic 24.0 software for Mac was used for all statistical analyses.

\section{Results}

All sixty randomized participants ( $\mathrm{n}=20$ in the $10 \mathrm{kHz}$ group, $\mathrm{n}=20$ in the $20 \mathrm{kHz}$ group, and $\mathrm{n}=20$ in the sham group) completed the trial and were included in the statistical analyses (Figure 2). Table 1 shows the demographic characteristics of the participants. No intergroup differences in demographic variables were found at baseline.

The applied current intensity was higher in the $20 \mathrm{kHz}$ group (3.7 mA; SD 2.3) than in the $10 \mathrm{kHz}$ group (1.8 mA; SD 1.3) $(p=0.03)$ at the beginning of the intervention, and also at the end of the intervention the intensity was higher in the 20 $\mathrm{kHz}$ group (12 mA; SD 5.3) compared to the $10 \mathrm{kHz}$ group (6 mA; SD 3.8) ( $p<0.001$ ). The mean current density was 42.8 $\mathrm{mA} / \mathrm{cm}^{2}$ and $21.4 \mathrm{~mA} / \mathrm{cm}^{2}$ for the $20 \mathrm{kHz}$ and $10 \mathrm{kHz}$ groups, respectively. The raw results for all variables can be found in the supplementary material (Supplementary Appendix 1).

\section{Maximum isometric finger flexion strength and myotonometry}

Table 2 shows the outcomes of MFFS and myotonometry in the study groups across the intervention. 
Significant differences in MFFS values were observed in the time factor $(F=17.2 ; p<0.001)$ but not in the timeintervention intersection ( $\mathrm{F}=2.4 ; p=0.07$ ). The MFFS decreased both in the $10 \mathrm{kHz}$ and $20 \mathrm{kHz}$ groups immediately postintervention and 15 minutes after its finalization versus baseline, in contrast to the sham group where no changes were observed.

In terms of myotonometry results, changes in the frequency were observed in the time factor $(F=7.6 ; p<0.001)$ and the time-intervention intersection $(\mathrm{F}=2.4 ; p=0.03)$. With respect to baseline, the frequency increased in the $10 \mathrm{kHz}$ group during the intervention and in the $20 \mathrm{kHz}$ group both immediately and at 15 minutes post-intervention. However, no changes were recorded in the sham group. Differences in the logarithmic decrement were observed in the time factor $(\mathrm{F}=4.8 ; p=0.003)$ but not in the time-intervention section ( $\mathrm{F}=1.2 ; p=0.29)$. The decrement increased in the $10 \mathrm{kHz} g r o u p$ during the intervention and 15 minutes after its finalization versus baseline, with no changes in the $20 \mathrm{kHz}$ and sham groups. Changes in stiffness measured with myotonometry were noted in the time factor $(F=14.7 ; p<0.001)$ and the time-intervention intersection ( $F=4.0 ; p=0.001)$. Stiffness increased with respect to baseline in the $10 \mathrm{kHz}$ group during and immediately after the intervention and in the $20 \mathrm{kHz}$ group immediately and at 15 minutes post-intervention, in contrast to the sham group where no changes were observed.

Table 3 shows the intergroup comparison of the intervention effect on these variables. Between-group differences in strength were observed immediately post-intervention ( $\mathrm{F}=4.6 ; p=0.01)$, specifically a greater strength loss of $-10.8 \%$ (CI95\% -19.8 to 1.8) in the $20 \mathrm{kHz}$ compared to the sham group. No other intergroup differences were reported.

Between-group differences in the frequency measured with myotonometry were observed immediately post-intervention $(\mathrm{F}=3.6 ; p=0.03)$, specifically an increase in the frequency in the $20 \mathrm{kHz}$ group versus the sham group. However, no intergroup significant differences in the effect on the decrement and stiffness were observed.

\section{Pressure pain threshold and mechanical detection threshold}

No differences were found in the PPT in the time factor $(\mathrm{F}=2.4 ; p=0.08)$ (Table 2$)$ or in the time-intervention intersection $(\mathrm{F}=0.5 ; p=0.78)$. Also, no differences were observed in the intergroup comparison of the effect on the PPT (Table 3).

The MDT changed over time (Friedman test $p=0.003$ ), but without reaching statistically significant differences in the post-hoc analysis (Tukey's test $p>0.05$; mean ranks: pre-intervention $=2.3 \mathrm{mN}$; during the intervention after 15 minutes $=2.7 \mathrm{mN}$; immediately post-intervention $=2.5 \mathrm{mN}$; at 15 min post-intervention=2.5 $\mathrm{mN}$ ). No intergroup differences were observed at any time point (Kruskal-Wallis test $p>0.05$ ).

\section{Antidromic sensory nerve action potential (SNAP) and temperature}

No significant differences in the median nerve conduction speed were observed in the time factor $(\mathrm{F}=2.4 ; p=0.11)$ or in the time-intervention intersection $(F=0.6 ; p=0.60)$. Significant differences in the potential amplitude were recorded in the time factor $(\mathrm{F}=4.8 ; p=0.01)$ but not in the post-hoc comparison or in the time-intervention intersection $(\mathrm{F}=0.3 ; p=0.88)$ (Table 2). No intergroup differences were also observed in the comparison of the intervention effect on both the conduction speed and potential amplitude (Table 3).

Significant changes in the hand temperature were noted in the time factor $(\mathrm{F}=6.9 ; p=0.002)$ but without differences in the post-hoc analysis. No changes were recorded in the time-intervention intersection ( $F=0.3 ; p=0.87$ ) (Table 2). In terms of forearm temperature, no differences were found in the time factor $(\mathrm{F}=0.2 ; p=0.82)$ or the time-intervention intersection ( $\mathrm{F}=1.5 ; p=0.21$ ) (Table 2). Similarly, no intergroup differences were observed in the comparison of the hand and forearm temperatures (Table 3).

Subjective variables and adverse effects

Page $7 / 20$ 
Table 4 shows the outcomes of subjective variables. Significant intergroup differences were only found in the tingling sensation, and statistical significance was nearly reached in the sensation of strength loss $\left(\chi^{2}: 5.71 ; p=0.057\right)$.

An unexpected adverse effect was only recorded for one participant in the sham stimulation group. The subject reported a feeling of pain in the forearm and towards the hand that disappeared 48 hours after the punction.

\section{Blinding assessment}

Table 5 shows the blinding assessment outcomes for the assessor and participants. The analysis of global blinding, as measured via James' index [39], yielded the successful blinding of participants and the lack of blinding of the assessor. In the blinding assessment by groups (active and sham) using Bang's index [38,40], a lack of blinding of both the participants and evaluator in the active group was observed, with $80 \%$ and $52 \%$ of correctly guessing the group allocation, respectively. In the sham group, $72 \%$ of participants thought they were assigned to the active group (opposite guess) and the assessor showed a lack of blinding by guessing the group allocation in $47 \%$ of cases.

\section{Discussion}

This is the first clinical trial delivering percutaneous ultrasound guided HFAC at frequencies of $10 \mathrm{kHz}$ and $20 \mathrm{kHz}$ to the median nerve of healthy volunteers. The outcomes of $10 \mathrm{kHz}$ and $20 \mathrm{kHz}$ HFAC stimulation showed a reduction in the MFFS and an increase in frequency and stiffness measured with myotonometry in both groups when compared to baseline. However, only the $20 \mathrm{kHz}$ group, with a decrease of $10.8 \%$ in MFFS and an increase of $6.7 \%$ in the frequency during myotonometry, reached a significant difference in myotonometry compared to the sham stimulation.

Preclinical studies $[5,41]$ suggest that HFAC produces a selective blockade of certain nerve fibers, which can be partial and quickly reversible depending on the frequency and intensity of the delivered current [17]. Nerve fibers react in different ways to nerve blockade depending on the conduction speed [42]. The block threshold varies for each fiber type and also as a function of the stimulation frequency $[2,43]$.

The subjective perception of tingling and strength loss that the present study observed are in agreement with the objective measure of the strength, myotonometry, and MDT variables. The reported adverse effects, such as a cold feeling, post-puncture pain, or heaviness in the area, were light and appeared equally in both active groups, so the percutaneous application of HFAC could be considered a safe technique with minimum associated risks as well as less invasive and with fewer complications than interventions with implanted electrodes that occasionally require repeated interventions for electrode replacement or result in scarring around the implantation area [19]. No participant in the present trial reported a feeling of heat or temperature increase in the application area during the HFAC stimulation, contrary to the studies by Zannou et al. [44-45] that observed a temperature increase in the tissues surrounding the electrodes during the application of $10 \mathrm{kHz}$ currents on the spinal cord simulated by implanted electrodes.

No changes were found in the proximal temperature, in contrast to the decrease in the distal temperature observed in all groups, which could be explained by the percutaneous application of needles. Animal studies have shown that body temperature affects nerve conduction [46-47]. The similar effect on temperature observed in all the intervention groups appears to indicate a lack of effect on the autonomic nervous system. To date, selective blocking of the autonomic nervous system (48) has been shown only with the application of toxins in animals. Future research should assess the effect of HFAC on the autonomic nervous system by including specific variables, such as skin flow measured with Doppler laser.

This study observed changes in the motor function but not in the sensory function of the nerve, which could be the result of a specific effect of HFAC on conduction in myelinated Aa-fibers. The decrease in the MFFS obtained with 10 
$\mathrm{kHz}$ and $20 \mathrm{kHz}$ currents occurred immediately after the application ended and the effect persisted up to 15 minutes. These findings are in agreement with those by Springer et al. [11] which delivered transcutaneous HFCA to the cubital nerve and evidenced an effect that persisted up to 10 minutes after stimulation. Similar to the outcomes of the present study, Kim et al. [9] and Serrano et al. [10,12] reported a reduction in strength with the transcutaneous application of currents, although this decrease was greater during the application of HFCA. The current study could not assess the effect on strength during the percutaneous application of currents due to the above-mentioned methodological reasons. Further research should delve into the effects on motor fibers during the percutaneous application of currents.

In the present study, an increase in myotonometry was found when delivering frequencies of $10 \mathrm{kHz}$ and $20 \mathrm{kHz}$. However, based on the positive correlation between muscle strength and stiffness observed in previous studies $[49,27,50]$, our initial hypothesis was that nerve block would reduce the tone and stiffness, as well as voluntary strength. However, the reduction in muscle strength and the increase in tone and stiffness could be related to a minimal increase in the "non-effective" basal contraction that occurs due to current stimulation. Although the intensity was adjusted below the motor threshold, a small sub-threshold contraction could occur that does not interfere with the real nerve block and the decrease in muscle strength. The real impact of this finding should be evaluated in patients with alterations in muscle tone to determine if an amelioration of clinical symptoms such as spasticity, clonus, or tremors can be observed.

The present study did not observe intergroup differences in somatosensory thresholds (PPT dependent on A $\delta$-fibers and MDT dependent on Aß-fibers). This is in contrast to the findings of Avendaño et al. [8], which applied $5 \mathrm{KHz}$ transcutaneous HFAC and reported changes in both the PPT and MDT, although these could stem from mechanisms that are unrelated to those involved in nerve blocking [51]. The results in the $20 \mathrm{kHz}$ intervention in the present study were similar to those obtained by Serrano et al. [12] applying transcutaneous HFAC. Unlike the results of the current trial, which did not find an effect on the PPT or MDT, Kim et al. [9] delivered $10 \mathrm{kHz}$ currents and determined that the PPT increased as a function of current frequency. The SNAPs, which are dependent on A $\beta$-fibers, also did not show detectable changes in the potential amplitude or the conduction speed, unlike the study by Avendaño et al. [8] that observed changes in these variables with the application of $5 \mathrm{kHz}$ HFCA currents. This can be due to the lower frequency that $A \beta$-fibers need for reaching nerve block $[5,41,42]$, although the mechanisms underlying this effect are not clear yet [52].

Although the intensities applied in this work were lower than in transcutaneous application, the values of current density were much higher than in the trials by Serrano et al. [10,12] and Avendaño et al. [8]. As the current frequency increases, higher intensity is required to reach the nerve block threshold $[2,43]$. Further studies applying higher frequencies are warranted to determine the intensity needed to attain the nerve block of the different nerve fibers without causing damage to the nerve.

Some studies have shown that the effect on nerve conduction is reversible, with a $\sim 10$-minute recovery time $[10,11,17,41]$. The present trial found that this effect can persist for up to 15 minutes after ending the intervention with HFAC. The protocol followed in this work could have significant clinical potential in pathologies involving the hyperactivity of the second motor neuron, such as spasticity, tremors, or hypertonia, due to the duration of the effect on motor fibers. Future research on the selective effect of HFAC on nerve conduction is of interest in order to determine the optimal frequency and intensity resulting in a greater effect on the sensory and motor function of nerves.

\section{Study limitations}

Given the methodological limitations inherent to the percutaneous application of currents, neurophysiological variables and MFFS could not be measured during the intervention and therefore the effect of the intervention on these variables 
could not be analyzed. The blinding assessment revealed a lack of blinding of the assessor, both globally and by groups, which can result in a detection bias. Future studies with sham stimulation enabling the blinding of assessors are warranted. Another limitation was that the sample comprised exclusively healthy volunteers, so translating these outcomes to clinical practice must be done with caution until further research in patients is conducted that determines the real therapeutic impact of HFAC.

\section{Conclusions}

The percutaneous ultrasound-guided application of HFAC at $10 \mathrm{kHz}$ and $20 \mathrm{kHz}$ frequencies to the median nerve produced a reversible effect on the motor function of the nerve, with a 15-minute recovery time after the finalization of the intervention. A decrease in the MFFS and increases in the logarithmic decrement, oscillation frequency, and muscle stiffness were observed, which were even greater in the $20 \mathrm{kHz}$ group. The percutaneous application of HFAC is a safe procedure with minimum associated risks that displays great potential for treating pathologies affecting the motor function of the nerve without substantial changes in the sensory pathways.

\section{Abbreviations}

ANOVA: analysis of variance; HFAC: high-frequency alternating currents; MDT: mechanical detection threshold; MFFS: maximal flexion finger strength; PPT: pressure pain threshold; SNAP: sensory nerve action potential; SD: standard deviation.

\section{Declarations}

Ethics approval and consent to participate: The ethics committee of the "Complejo Hospitalario de Toledo" approved this study and warranted it was conducted in accordance with the Declaration of Helsinki (number 441; 11/11/2019). Written informed consent was obtained from all participants prior to their participation.

Consent for publication: Not applicable.

Availability of data and material: Original datasets are available in the Zenodo repository at DOI: https://doi.org/10.5281/zenodo.5840197

Competing interests: Avendaño-Coy and Gómez-Soriano own a patent of a device that evokes electrical currents between $10 \mathrm{kHz}$ and $50 \mathrm{kHz}$. However, this device has not been used in this work. The remaining authors have no conflicts of interest.

Funding: This work received the grant PID2020-119752RA-I00 funded by MCIN/AEI/10.13039/501100011033 and the "European Regional Development Fund (ERDF), A way of making Europe" or the "Next Generation EU/PRTR", as appropriate. DSM has received funding by the European Regional Development Fund (2019/7375).

Author's contribution: DMC, DSM, and JJFP contributed to the recruitment of participants, data collection, and drafting of the manuscript. JAC, JGS, and DSM conceived the study, interpreted the results, and supervised the whole project. All authors read and approved the final manuscript.

\section{References}

1. Kilgore KL, Bhadra N. Nerve conduction block utilising high-frequency alternating current. Med Biol Eng Comput. 2004;42(3):394-406.

Page $10 / 20$ 
2. Bhadra N, Kilgore KL. High-frequency electrical conduction block of mammalian peripheral motor nerve. Muscle Nerve. 2005;32(6):782-90.

3. Bhadra N, Bhadra N, Kilgore K, Gustafson KJ. High frequency electrical conduction block of the pudendal nerve. J Neural Eng. 2006;3(2):180-7.

4. Ackermann DM, Ethier C, Foldes EL, Oby ER, Tyler D, Bauman M, et al. Electrical conduction block in large nerves: high-frequency current delivery in the nonhuman primate. Muscle Nerve. 2011;43(6):897-9.

5. Bhadra N, Lahowetz EA, Foldes ST, Kilgore KL. Simulation of high-frequency sinusoidal electrical block of mammalian myelinated axons. J Comput Neurosci. 2007;22(3):313-26.

6. Tai C, Roppolo JR, de Groat WC. Block of external urethral sphincter contraction by high frequency electrical stimulation of pudendal nerve. J Urol. 2004;172(5 Pt 1):2069-72.

7. Avendano-Coy J, Serrano-Munoz D, Taylor J, Goicoechea-Garcia C, Gomez-Soriano J. Peripheral Nerve Conduction Block by High-Frequency Alternating Currents: A Systematic Review. IEEE Trans Neural Syst Rehabil Eng Publ IEEE Eng Med Biol Soc. 2018;26(6):1131-40.

8. Avendaño-Coy J, Gómez-Soriano J, Goicoechea-García C, Basco-López JA, Taylor J. Effect of Unmodulated 5-kHz Alternating Currents Versus Transcutaneous Electrical Nerve Stimulation on Mechanical and Thermal Pain, Tactile Threshold, and Peripheral Nerve Conduction: A Double-Blind, Placebo-Controlled Crossover Trial. Arch Phys Med Rehabil. 2017;98(5):888-95.

9. Kim Y, Cho H-J, Park H-S. Technical development of transcutaneous electrical nerve inhibition using mediumfrequency alternating current. J Neuroengineering Rehabil. 2018;15(1):80.

10. Serrano-Muñoz D, Avendaño-Coy J, Simón-Martínez C, Taylor J, Gómez-Soriano J. Effect of high-frequency alternating current transcutaneous stimulation over muscle strength: a controlled pilot study. J Neuroengineering Rehabil. 2018;15(1):103.

11. Springer S, Kozol Z, Reznic Z. Ulnar Nerve Conduction Block Using Surface Kilohertz Frequency Alternating Current: A Feasibility Study. Artif Organs. 2018;42(8):841-6.

12. Serrano-Muñoz D, Avendaño-Coy J, Simón-Martínez C, Taylor J, Gómez-Soriano J. 20-kHz alternating current stimulation: effects on motor and somatosensory thresholds. J NeuroEngineering Rehabil. 2020;17(1):22.

13. Ackermann DM, Foldes EL, Bhadra N, Kilgore KL. Effect of Bipolar Cuff Electrode Design on Block Thresholds in High-Frequency Electrical Neural Conduction Block. IEEE Trans Neural Syst Rehabil Eng Publ IEEE Eng Med Biol Soc. 2009;17(5):469-77.

14. Soin A, Shah NS, Fang Z-P. High-frequency electrical nerve block for postamputation pain: a pilot study. Neuromodulation J Int Neuromodulation Soc. 2015;18(3):197-205;

15. Rubinstein JT, Tyler RS, Johnson A, Brown CJ. Electrical suppression of tinnitus with high-rate pulse trains. Otol Neurotol Off Publ Am Otol Soc Am Neurotol Soc Eur Acad Otol Neurotol. 2003;24(3):478-85.

16. Ackermann DM, Foldes EL, Bhadra N, Kilgore KL. Conduction Block of Peripheral Nerve Using High Frequency Alternating Currents Delivered through an Intrafascicular Electrode. Muscle Nerve. 2010;41(1):117-9.

17. Dowden BR, Wark HAC, Normann RA. Muscle-selective block using intrafascicular high-frequency alternating current. Muscle Nerve. 2010;42(3):339-47.

18. Williamson RP, Andrews BJ. Localized electrical nerve blocking. IEEE Trans Biomed Eng. 2005;52(3):362-70.

19. Finch P, Price L, Drummond P. High-Frequency $(10 \mathrm{kHz})$ Electrical Stimulation of Peripheral Nerves for Treating Chronic Pain: A Double-Blind Trial of Presence vs Absence of Stimulation. Neuromodulation Technol Neural Interface. 2019;22(5):529-36. 
20. Eldabe S, Buchser E, Duarte RV. Complications of Spinal Cord Stimulation and Peripheral Nerve Stimulation Techniques: A Review of the Literature. Pain Med Malden Mass. 2016;17(2):325-36.

21. Invited Faculty Abstracts from the International Neuromodulation Society's 14th World Congress. Neuromodulation 2019;22(7):e354.

22. Claydon LS, Chesterton LS, Barlas P, Sim J. Alternating-frequency TENS effects on experimental pain in healthy human participants: a randomized placebo-controlled trial. Clin J Pain. 2013;29(6):533-9.

23. Serrano-Muñoz D, Gómez-Soriano J, Bravo-Esteban E, Vázquez-Fariñas M, Taylor J, Avendaño-Coy J. Intensity matters: Therapist-dependent dose of spinal transcutaneous electrical nerve stimulation. PloS One. 2017;12(12)

24. Mentiplay BF, Perraton LG, Bower KJ, Adair B, Pua Y-H, Williams GP, et al. Assessment of Lower Limb Muscle Strength and Power Using Hand-Held and Fixed Dynamometry: A Reliability and Validity Study. PLOS ONE. 2015;10(10):e0140822.

25. Shiratori AP, lop R da R, Júnior NGB, Domenech SC, Gevaerd M da S. Evaluation protocols of hand grip strength in individuals with rheumatoid arthritis: a systematic review. Rev Bras Reumatol Engl Ed. 2014;54(2):140-7.

26. Chuang L-L, Lin K-C, Wu C-Y, Chang C-W, Chen H-C, Yin H-P, et al. Relative and absolute reliabilities of the myotonometric measurements of hemiparetic arms in patients with stroke. Arch Phys Med Rehabil. 2013;94(3):459-66.

27. Gavronski G, Veraksits A, Vasar E, Maaroos J. Evaluation of viscoelastic parameters of the skeletal muscles in junior triathletes. Physiol Meas. 2007;28(6):625-37.

28. Ristić D, Spangenberg P, Ellrich J. Analgesic and antinociceptive effects of peripheral nerve neurostimulation in an advanced human experimental model. Eur J Pain Lond Engl. 2008;12(4):480-90.

29. Nilsson HJ, Schouenborg J. Differential inhibitory effect on human nociceptive skin senses induced by local stimulation of thin cutaneous fibers. Pain. 1999;80(1-2):103-12.

30. Chesterton LS, Barlas P, Foster NE, Lundeberg T, Wright CC, Baxter GD. Sensory stimulation (TENS): effects of parameter manipulation on mechanical pain thresholds in healthy human subjects. Pain. 2002;99(1-2):253-62.

31. Nussbaum EL, Downes L. Reliability of clinical pressure-pain algometric measurements obtained on consecutive days. Phys Ther. 1998;78(2):160-9.

32. Antonaci F, Bovim G, Fasano ML, Bonamico L, Shen JM. Pain threshold in humans. A study with the pressure algometer. Funct Neurol. 1992;7(4):283-8.

33. Antonaci F, Sand T, Lucas GA. Pressure algometry in healthy subjects: inter-examiner variability. Scand J Rehabil Med. 1998;30(1):3-8.

34. Fischer AA. Pressure algometry over normal muscles. Standard values, validity and reproducibility of pressure threshold. Pain. 1987;30(1):115-26.

35. Valls-Sole J, Leote J, Pereira P. Antidromic vs orthodromic sensory median nerve conduction studies. Clin Neurophysiol Pract. 2016;1:18-25.

36. Walsh DM, Lowe AS, McCormack K, Willer JC, Baxter GD, Allen JM. Transcutaneous electrical nerve stimulation: effect on peripheral nerve conduction, mechanical pain threshold, and tactile threshold in humans. Arch Phys Med Rehabil. 1998;79(9):1051-8.

37. Letz R, Gerr F. Covariates of human peripheral nerve function: I. Nerve conduction velocity and amplitude. Neurotoxicol Teratol. 1994;16(1):95-104.

38. Bang H, Flaherty SP, Kolahi J, Park J. Blinding assessment in clinical trials: A review of statistical methods and a proposal of blinding assessment protocol. Clin Res Regul Aff. 2010;27(2):42-51. 
39. James KE, Bloch DA, Lee KK, Kraemer HC, Fuller RK. An index for assessing blindness in a multi-centre clinical trial: disulfiram for alcohol cessation-a VA cooperative study. Stat Med. 1996;15(13):1421-34.

40. Bang H, Ni L, Davis CE. Assessment of blinding in clinical trials. Control Clin Trials. 2004;25(2):143-56.

41. Waataja JJ, Tweden KS, Honda CN. Effects of high-frequency alternating current on axonal conduction through the vagus nerve. J Neural Eng. 2011;8(5):056013.

42. Patel YA, Butera RJ. Differential fiber-specific block of nerve conduction in mammalian peripheral nerves using kilohertz electrical stimulation. J Neurophysiol. 2015;113(10):3923-9.

43. Joseph L, Butera RJ. High Frequency Stimulation Selectively Blocks Different Types of Fibers in Frog Sciatic Nerve. leee Trans Neural Syst Rehabil Eng. 2011;19(5):550-7.

44. Zannou AL, Khadka N, Truong DQ, Zhang T, Esteller R, Hershey B, et al. Temperature Increases by kilohertz frequency Spinal Cord Stimulation. Brain Stimulat. 2019;12(1):62-72.

45. Zannou AL, Khadka N, FallahRad M, Truong DQ, Kopell BH, Bikson M. Tissue Temperature Increases by HF10 Spinal Cord Stimulation System: A Phantom Study and Bioheat Model. Neuromodulation. 2019: 10.111/ ner12980.

46. Tai C, Wang J, Chancellor MB, Roppolo JR, de Groat WC. Influence of Temperature on Pudendal Nerve Block Induced by High-Frequency Biphasic Electrical Current. J Urol. 2008;180(3):1173-8.

47. Wang J, Shen B, Roppolo JR, de Groat WC, Tai C. Influence of Frequency and Temperature on the Mechanisms of Nerve Conduction Block Induced by High-Frequency Biphasic Electrical Current. J Comput Neurosci. 2008;24(2):195.

48. Stürzebecher AS, Hu J, Smith ESJ, Frahm S, Santos-Torres J, Kampfrath B, et al. An in vivo tethered toxin approach for the cell-autonomous inactivation of voltage-gated sodium channel currents in nociceptors. J Physiol. 2010;588(Pt 10):1695-707.

49. Fröhlich-Zwahlen AK, Casartelli NC, Item-Glatthorn JF, Maffiuletti NA. Validity of resting myotonometric assessment of lower extremity muscles in chronic stroke patients with limited hypertonia: a preliminary study. J Electromyogr Kinesiol Off J Int Soc Electrophysiol Kinesiol. 2014;24(5):762-9.

50. Bizzini M, Mannion AF. Reliability of a new, hand-held device for assessing skeletal muscle stiffness. Clin Biomech. 2003;18(5):459-61.

51. Walsh DM, Lowe AS, McCormack K, Willer JC, Baxter GD, Allen JM. Transcutaneous electrical nerve stimulation: effect on peripheral nerve conduction, mechanical pain threshold, and tactile threshold in humans. Arch Phys Med Rehabil. 1998;79(9):1051-8.

52. Neudorfer C, Chow CT, Boutet A, Loh A, Germann J, Elias GJB, et al. Kilohertz-frequency stimulation of the nervous system: A review of underlying mechanisms. Brain Stimulat. 2021;14(3):513-30.

\section{Tables}

Table 1: Demographic characteristics of participants at baseline. 


\begin{tabular}{|c|c|c|c|c|c|}
\hline Outcomes & $\begin{array}{l}\text { All participants } \\
(n=60)\end{array}$ & $\begin{array}{l}10 \mathrm{kHz} \\
\text { group } \\
(\mathrm{n}=20)\end{array}$ & $\begin{array}{l}20 \mathrm{kHz} \text { group } \\
(\mathrm{n}=20)\end{array}$ & $\begin{array}{l}\text { Sham } \\
\text { group } \\
(n=20)\end{array}$ & $\begin{array}{l}\text { Between groups } \\
\text { differences } \\
\text { (p value) }\end{array}$ \\
\hline $\begin{array}{l}\text { Age (years) } \\
\text { Mean (SD) }\end{array}$ & $21.6(3.4)$ & $22.9(4.8)$ & $20.8(1.9)$ & $21.0(2.5)$ & $(p=0.09)^{a}$ \\
\hline $\begin{array}{l}\text { Gender } \\
\text { (Male/ Female) } \\
\text { n (\%) }\end{array}$ & $\begin{array}{l}26(43.3 \%) / \\
34(56.7 \%)\end{array}$ & $\begin{array}{l}11(45.0 \%) \\
9(55.0 \%)\end{array}$ & $\begin{array}{l}9(55.0 \%) / \\
11(45.0 \%)\end{array}$ & $\begin{array}{l}6(30.0 \\
\%) / \\
14(70.0 \\
\%)\end{array}$ & $(p=0.28)^{b}$ \\
\hline $\begin{array}{l}\text { Weight }(\mathbf{k g}) \\
\text { Mean (SD) }\end{array}$ & $67.5(13.2)$ & $\begin{array}{l}71.7 \\
(15.7)\end{array}$ & $65.2(11.6)$ & $\begin{array}{l}65.5 \\
(11.6)\end{array}$ & $(p=0.21)^{a}$ \\
\hline $\begin{array}{l}\text { Height (m) } \\
\text { Mean (SD) }\end{array}$ & $1.70(0.09)$ & $\begin{array}{l}1.74 \\
(0.10)\end{array}$ & $1.69(0.07)$ & $\begin{array}{l}1.68 \\
(0.09)\end{array}$ & $(p=0.09)^{a}$ \\
\hline $\begin{array}{l}\text { Body mass index } \\
\left(\mathrm{kg} / \mathrm{m}^{2}\right) \\
\text { Mean (SD) }\end{array}$ & $23.2(3.2)$ & 23.7 (3.9) & $22.6(3.3)$ & $23.2(2.4)$ & $(p=0.56)^{a}$ \\
\hline $\begin{array}{l}\text { Non-dominant hand } \\
\text { (Left/Right) } \\
\mathrm{n}(\%)\end{array}$ & $\begin{array}{l}57(95.0 \%) / \\
3(5.0 \%)\end{array}$ & $\begin{array}{l}19(95.0 \%) \\
1(5.0 \%)\end{array}$ & $\begin{array}{l}20(100.0 \%) / \\
0(0.0 \%)\end{array}$ & $\begin{array}{l}18(90.0 \\
\%) / \\
2(10.0 \\
\%)\end{array}$ & $(p=0.77)^{c}$ \\
\hline
\end{tabular}

Statistical test: a) one way analysis of variance (oneway ANOVA), b) Pearson's chi-squared test, c) Fisher's exact test.

Table 2: Intragroup comparison from baseline. 


\begin{tabular}{|c|c|c|c|c|c|c|c|c|c|}
\hline \multirow{3}{*}{$\begin{array}{l}\text { Outcomes } \\
\% \text { Mean } \\
(\mathrm{Cl} 95 \%)\end{array}$} & \multicolumn{9}{|c|}{ Intra-group comparison from baseline } \\
\hline & \multicolumn{3}{|c|}{ Sham group } & \multicolumn{3}{|c|}{$10 \mathrm{kHz}$ group } & \multicolumn{3}{|c|}{$20 \mathrm{kHz}$ group } \\
\hline & $\begin{array}{l}\text { During } \\
\text { minus } \\
\text { Pre }\end{array}$ & $\begin{array}{l}\text { Post } 0 \\
\text { minus } \\
\text { Pre }\end{array}$ & $\begin{array}{l}\text { Post } \\
15 \\
\text { minus } \\
\text { Pre }\end{array}$ & $\begin{array}{l}\text { During } \\
\text { minus } \\
\text { Pre }\end{array}$ & $\begin{array}{l}\text { Post } 0 \\
\text { minus } \\
\text { Pre }\end{array}$ & $\begin{array}{l}\text { Post } \\
15 \\
\text { minus } \\
\text { Pre }\end{array}$ & $\begin{array}{l}\text { During } \\
\text { minus } \\
\text { Pre }\end{array}$ & $\begin{array}{l}\text { Post } 0 \\
\text { minus } \\
\text { Pre }\end{array}$ & $\begin{array}{l}\text { Post } \\
15 \\
\text { minus } \\
\text { Pre }\end{array}$ \\
\hline \multirow[t]{2}{*}{ Strength } & \multirow[t]{2}{*}{ NA } & -1.1 & -3.5 & \multirow[t]{2}{*}{ NA } & $-8.5^{* *}$ & $-9.5^{*}$ & \multirow[t]{2}{*}{ NA } & $-12.0^{* *}$ & $-11.5^{* *}$ \\
\hline & & $\begin{array}{l}(-7.5 \text { to } \\
5.2)\end{array}$ & $\begin{array}{l}(-11.3 \\
\text { to } 4.2)\end{array}$ & & $\begin{array}{l}(-14.9 \\
\text { to }-2.1)\end{array}$ & $\begin{array}{l}(-17.3 \\
\text { to }-1.8)\end{array}$ & & $\begin{array}{l}(-18.3 \\
\text { to } \\
-5.6)\end{array}$ & $\begin{array}{l}(-9.3 \text { to } \\
-3.8)\end{array}$ \\
\hline \multirow{2}{*}{$\begin{array}{l}\text { Myotonometry } \\
\text { Frequency }\end{array}$} & 1.7 & 0.4 & 1.6 & $6.8^{\star *}$ & 3.8 & 3.1 & 4.3 & $7.1^{* *}$ & $6.7^{\star \star}$ \\
\hline & $\begin{array}{l}(-3.7 \text { to } \\
7.0)\end{array}$ & $\begin{array}{l}(-4.4 \text { to } \\
5.1)\end{array}$ & $\begin{array}{l}(-2.7 \text { to } \\
6.0)\end{array}$ & $\begin{array}{l}\text { (1.3 to } \\
12.3)\end{array}$ & $\begin{array}{l}(-1.1 \text { to } \\
8,6)\end{array}$ & $\begin{array}{l}(-1.4 \text { to } \\
7.5)\end{array}$ & $\begin{array}{l}(-1.4 \\
\text { to } \\
10.0)\end{array}$ & $\begin{array}{l}(2.1 \text { to } \\
12.1)\end{array}$ & $\begin{array}{l}\text { (2.1 to } \\
11.3)\end{array}$ \\
\hline Myotonometry & -1.6 & 0.8 & 3.6 & $10,1^{*}$ & 7.5 & $11.0^{* *}$ & 2.4 & 3.9 & 6.3 \\
\hline Decrement & $\begin{array}{l}(-11.5 \text { to } \\
8.2)\end{array}$ & $\begin{array}{l}(-7.9 \text { to } \\
9.6)\end{array}$ & $\begin{array}{l}(-4.7 \text { to } \\
12.0)\end{array}$ & $\begin{array}{l}(0.1 \text { to } \\
20.2)\end{array}$ & $\begin{array}{l}(-1.4 \text { to } \\
16.5)\end{array}$ & $\begin{array}{l}(2.4 \text { to } \\
19.5)\end{array}$ & $\begin{array}{l}(-8.0 \\
\text { to } \\
12.7)\end{array}$ & $\begin{array}{l}(-5.4 \\
\text { to } \\
13.1)\end{array}$ & $\begin{array}{l}(-2.5 \text { to } \\
15.1)\end{array}$ \\
\hline Myotonometry & 4.7 & 2.6 & 2.5 & $10.7^{* \star}$ & $6.3^{*}$ & 2.4 & 4.7 & $8.5^{\star *}$ & $8.0^{* *}$ \\
\hline Stiffness & $\begin{array}{l}(-1.1 \text { to } \\
10.4)\end{array}$ & $\begin{array}{l}(-2.5 \text { to } \\
7.8)\end{array}$ & $\begin{array}{l}(-2.5 \text { to } \\
7.4)\end{array}$ & $\begin{array}{l}\text { (4.8 to } \\
16.6)\end{array}$ & $\begin{array}{l}(1.0 \text { to } \\
11.6)\end{array}$ & $\begin{array}{l}(-2.7 \text { to } \\
7.5)\end{array}$ & $\begin{array}{l}(-1.4 \\
\text { to } \\
10.7)\end{array}$ & $\begin{array}{l}\text { (3.1 to } \\
13.9)\end{array}$ & $\begin{array}{l}\text { (2.8 to } \\
13.2)\end{array}$ \\
\hline \multirow{2}{*}{$\begin{array}{l}\text { Pain Pressure } \\
\text { Threshold }\end{array}$} & -6.5 & -6.2 & -7.4 & -7.9 & -0.7 & -2.6 & -4.6 & -5.6 & -4.3 \\
\hline & $\begin{array}{l}(-20.2 \text { to } \\
8.1)\end{array}$ & $\begin{array}{l}(-17.9 \text { to } \\
5.5)\end{array}$ & $\begin{array}{l}(-20.1 \\
\text { to } 5.3)\end{array}$ & $\begin{array}{l}(-22.1 \\
\text { to } 6.2)\end{array}$ & $\begin{array}{l}(-12.4 \\
\text { to } 11.0)\end{array}$ & $\begin{array}{l}(-15.3 \\
\text { to } \\
10.0)\end{array}$ & $\begin{array}{l}(-18.8 \\
\text { to } 9.5)\end{array}$ & $\begin{array}{l}(-17.2 \\
\text { to } \\
-6.1)\end{array}$ & $\begin{array}{l}(-16.9 \\
\text { to } 8.4)\end{array}$ \\
\hline \multirow{2}{*}{$\begin{array}{l}\text { Amplitude } \\
\text { SNAP }\end{array}$} & \multirow[t]{2}{*}{ NA } & 29.0 & 26.5 & \multirow[t]{2}{*}{ NA } & 21.8 & 20.9 & \multirow[t]{2}{*}{ NA } & 31.2 & 10.1 \\
\hline & & $\begin{array}{l}(-9.1 \text { to } \\
67.2)\end{array}$ & $\begin{array}{l}(-7.5 \text { to } \\
60.5)\end{array}$ & & $\begin{array}{l}(-16.4 \\
\text { to } 59.9)\end{array}$ & $\begin{array}{l}(-13.1 \\
\text { to } \\
54.9)\end{array}$ & & $\begin{array}{l}(-6.9 \\
\text { to } \\
69.3)\end{array}$ & $\begin{array}{l}(-23.9 \\
\text { to } \\
44.1)\end{array}$ \\
\hline \multirow{2}{*}{$\begin{array}{l}\text { Nerve Speed } \\
\text { Conduction }\end{array}$} & \multirow[t]{2}{*}{ NA } & -5.5 & -6.1 & \multirow[t]{2}{*}{ NA } & -0.1 & -0.4 & \multirow[t]{2}{*}{ NA } & -2.0 & -5.5 \\
\hline & & $\begin{array}{l}(-14.2 \text { to } \\
3.3)\end{array}$ & $\begin{array}{l}(-15.1 \\
\text { to } 2.9)\end{array}$ & & $\begin{array}{l}(-8.9 \text { to } \\
8.7)\end{array}$ & $\begin{array}{l}(-9.4 \text { to } \\
8.6)\end{array}$ & & $\begin{array}{l}(-10.8 \\
\text { to } \\
6.7)\end{array}$ & $\begin{array}{l}(-14.5 \\
\text { to } 3.5)\end{array}$ \\
\hline \multirow{2}{*}{$\begin{array}{l}\text { Forearm } \\
\text { Temperature }\end{array}$} & 0.8 & 0.7 & 0.8 & -1.6 & -1.4 & -2.1 & 1.2 & 0.9 & 0.6 \\
\hline & $\begin{array}{l}(-2.3 \text { to } \\
3.8)\end{array}$ & $\begin{array}{l}(-1.8 \text { to } \\
3.3)\end{array}$ & $\begin{array}{l}(-2.2 \text { to } \\
3.9)\end{array}$ & $\begin{array}{l}(-4.6 \\
\text { to } 1.5)\end{array}$ & $\begin{array}{l}(-3.9 \text { to } \\
1.2)\end{array}$ & $\begin{array}{l}(-5.2 \text { to } \\
1.0)\end{array}$ & $\begin{array}{l}(-1.8 \\
\text { to } 4.3)\end{array}$ & $\begin{array}{l}(-1.7 \\
\text { to } \\
3.4)\end{array}$ & $\begin{array}{l}(-2.5 \text { to } \\
3.7)\end{array}$ \\
\hline \multirow{2}{*}{$\begin{array}{l}\text { Hand } \\
\text { Temperature }\end{array}$} & -2.4 & -2.7 & -4.1 & -3.1 & -2.1 & -3.3 & -1.4 & -2.3 & -4.1 \\
\hline & $\begin{array}{l}(-7.5 \text { to } \\
2.7)\end{array}$ & $\begin{array}{l}(-7.1 \text { to } \\
1.6)\end{array}$ & $\begin{array}{l}(-9.2 \text { to } \\
1.0)\end{array}$ & $\begin{array}{l}(-8.2 \\
\text { to } 2.0)\end{array}$ & $\begin{array}{l}(-6.4 \text { to } \\
2.2)\end{array}$ & $\begin{array}{l}(-8.5 \text { to } \\
1.8)\end{array}$ & $\begin{array}{l}(-6.5 \\
\text { to } 3.7)\end{array}$ & $\begin{array}{l}(-6.7 \\
\text { to } \\
2.0)\end{array}$ & $\begin{array}{l}(-9.3 \text { to } \\
1.0)\end{array}$ \\
\hline
\end{tabular}

Bold values denote statistical significance: $\left(^{* *}\right) \mathrm{p}<0,01$ level; $\left.{ }^{*}\right) \mathrm{p}<0.05$ level. Abbreviations; PRE: Pre-intervention, NA: Not applicable. SNAP: Sensory nerve action potential. 
Table 3: Inter-group comparison in the change from baseline. 


\begin{tabular}{|c|c|c|c|c|c|c|c|c|c|}
\hline \multirow{3}{*}{$\begin{array}{l}\text { Outcomes } \\
\text { \% Mean } \\
\text { (CI95\%) }\end{array}$} & \multicolumn{9}{|c|}{ Inter-group comparison in the change from baseline } \\
\hline & \multicolumn{3}{|c|}{$\begin{array}{l}\text { Change Sham minus Change } \\
10 \mathrm{kHz}\end{array}$} & \multicolumn{3}{|c|}{$\begin{array}{l}\text { Change Sham minus Change } \\
20 \mathrm{kHz}\end{array}$} & \multicolumn{3}{|c|}{$\begin{array}{l}\text { Change } 10 \mathrm{kHz} \text { minus } \\
\text { Change } 20 \mathrm{kHz}\end{array}$} \\
\hline & $\begin{array}{l}\text { During } \\
\text { intervention }\end{array}$ & $\begin{array}{l}\text { Post } \\
0 \\
\text { min. }\end{array}$ & $\begin{array}{l}\text { Post } \\
15 \\
\text { min. }\end{array}$ & $\begin{array}{l}\text { During } \\
\text { intervention }\end{array}$ & $\begin{array}{l}\text { Post } \\
0 \\
\text { min. }\end{array}$ & $\begin{array}{l}\text { Post } \\
15 \\
\text { min. }\end{array}$ & $\begin{array}{l}\text { During } \\
\text { intervention }\end{array}$ & $\begin{array}{l}\text { Post } \\
0 \\
\text { min. }\end{array}$ & $\begin{array}{l}\text { Post } \\
15 \\
\text { min. }\end{array}$ \\
\hline \multirow[t]{2}{*}{ Strength } & NA & -7.3 & -6.0 & NA & $-10.8^{*}$ & -8.0 & NA & -3.5 & -2.0 \\
\hline & & $\begin{array}{l}(-16.4 \\
\text { to } \\
1.7)\end{array}$ & $\begin{array}{l}(-17.0 \\
\text { to } \\
5.0)\end{array}$ & & $\begin{array}{l}(-19.8 \\
\text { to- } \\
1.8)\end{array}$ & $\begin{array}{l}(-19.0 \\
\text { to } \\
3.0)\end{array}$ & & $\begin{array}{l}(-12.5 \\
\text { to } \\
5.5)\end{array}$ & $\begin{array}{l}(-13.0 \\
\text { to } \\
8.9)\end{array}$ \\
\hline \multirow{2}{*}{$\begin{array}{l}\text { Myotonometry } \\
\text { Frequency }\end{array}$} & 5.1 & 3.4 & 1.5 & 2.6 & $6.7^{*}$ & 5.1 & -2.5 & 3.3 & 3.6 \\
\hline & $\begin{array}{l}(-1.8 \text { to } \\
12.1)\end{array}$ & $\begin{array}{l}(-2.7 \\
\text { to } \\
9.5)\end{array}$ & $\begin{array}{l}(-4.1 \\
\text { to } \\
7.1)\end{array}$ & $(-4.4$ to 9.7$)$ & $\begin{array}{l}(0.5 \\
\text { to } \\
12.9)\end{array}$ & $\begin{array}{l}(-0.6 \\
\text { to } \\
10.8)\end{array}$ & $(-9.6$ to 4.7$)$ & $\begin{array}{l}(-2.9 \\
\text { to } \\
9.6)\end{array}$ & $\begin{array}{l}(-2.1 \\
\text { to } \\
9.4)\end{array}$ \\
\hline Myotonometry & 11.8 & 6.7 & 7.3 & 4.0 & 3.0 & 2.7 & -7.7 & -3.7 & -4.7 \\
\hline Decrement & $\begin{array}{l}(-1.0 \text { to } \\
24.5)\end{array}$ & $\begin{array}{l}(4.6 \\
\text { to } \\
18.0)\end{array}$ & $\begin{array}{l}(-3.5 \\
\text { to } \\
18.2)\end{array}$ & $\begin{array}{l}(-8.9 \text { to } \\
16.9)\end{array}$ & $\begin{array}{l}(-8,4 \\
\text { to } \\
14.5)\end{array}$ & $\begin{array}{l}(-8.3 \\
\text { to } \\
13.6)\end{array}$ & $\begin{array}{l}(-20.8 \text { to } \\
5.3)\end{array}$ & $\begin{array}{l}(-15.3 \\
\text { to } \\
7.9)\end{array}$ & $\begin{array}{l}(-15.8 \\
\text { to } \\
6.4)\end{array}$ \\
\hline Myotonometry & 6.1 & 3.7 & -0.1 & -0.02 & 5.8 & 5.5 & -6.0 & 2.2 & 5.6 \\
\hline Stiffness & $\begin{array}{l}(-1.4 \text { to } \\
13.5)\end{array}$ & $\begin{array}{l}(-3.0 \\
\text { to } \\
10.3)\end{array}$ & $\begin{array}{l}(-6.5 \\
\text { to } \\
6.3)\end{array}$ & $(-7.5$ to 7.5$)$ & $\begin{array}{l}(-0.9 \\
\text { to } \\
12.5)\end{array}$ & $\begin{array}{l}(-0.9 \\
\text { to } \\
12.0)\end{array}$ & $\begin{array}{l}(-13.7 \text { to } \\
1.6)\end{array}$ & $\begin{array}{l}(-4.6 \\
\text { to } \\
9.0)\end{array}$ & $\begin{array}{l}(-0.9 \\
\text { to } \\
12.2)\end{array}$ \\
\hline \multirow{2}{*}{$\begin{array}{l}\text { Pressure Pain } \\
\text { Threshold }\end{array}$} & -1.9 & 5.5 & 7.0 & 1.4 & 0.7 & 9.7 & 3.3 & -4.9 & 2.7 \\
\hline & $\begin{array}{l}(-20.0 \text { to } \\
16.2)\end{array}$ & $\begin{array}{l}(-9.4 \\
\text { to } \\
20.4)\end{array}$ & $\begin{array}{l}(-9.3 \\
\text { to } \\
23.3)\end{array}$ & $\begin{array}{l}(16.6 \text { to } \\
19.5)\end{array}$ & $\begin{array}{l}(-16.6 \\
\text { to } \\
14.3)\end{array}$ & $\begin{array}{l}(-6.6 \\
\text { to } \\
26.0)\end{array}$ & $\begin{array}{l}(-14.7 \text { to } \\
21.4)\end{array}$ & $\begin{array}{l}(19.8 \\
\text { to } \\
10.5)\end{array}$ & $\begin{array}{l}(-13.6 \\
\text { to } \\
19.0)\end{array}$ \\
\hline \multirow{2}{*}{$\begin{array}{l}\text { Amplitude } \\
\text { SNAP }\end{array}$} & NA & -7.3 & -5.5 & NA & 2.1 & -16.4 & NA & 9.4 & -10.9 \\
\hline & & $\begin{array}{l}(-61.2 \\
\text { to } \\
46.7)\end{array}$ & $\begin{array}{l}(-53.7 \\
\text { to } \\
42.6)\end{array}$ & & $\begin{array}{l}(-51.8 \\
\text { to } \\
56.1)\end{array}$ & $\begin{array}{l}(-64.5 \\
\text { to } \\
31.7)\end{array}$ & & $\begin{array}{l}(-44.5 \\
\text { to } \\
63.3)\end{array}$ & $\begin{array}{l}(-59.0 \\
\text { to } \\
37.3)\end{array}$ \\
\hline \multirow{2}{*}{$\begin{array}{l}\text { Nerve Speed } \\
\text { Conduction }\end{array}$} & NA & 5.4 & -3.6 & NA & -3.4 & -16.6 & NA & -1.9 & -13.0 \\
\hline & & $\begin{array}{l}(-7.0 \\
\text { to } \\
17.8)\end{array}$ & $\begin{array}{l}(-81.1 \\
\text { to } \\
73.9)\end{array}$ & & $\begin{array}{l}(-15.8 \\
\text { to } \\
9.0)\end{array}$ & $\begin{array}{l}(-94.1 \\
\text { to } \\
61.0)\end{array}$ & & $\begin{array}{l}(-14.3 \\
\text { to } \\
10.5)\end{array}$ & $\begin{array}{l}(-90.5 \\
\text { to } \\
64.6)\end{array}$ \\
\hline \multirow{2}{*}{$\begin{array}{l}\text { Forearm } \\
\text { Temperature }\end{array}$} & -2.3 & -2.7 & -2.9 & 0.5 & 0.1 & -0.2 & 2.8 & 2.2 & 2.7 \\
\hline & $(-6.2$ to 1.5$)$ & $\begin{array}{l}(-5.3 \\
\text { to } \\
1.2)\end{array}$ & $\begin{array}{l}(-6.9 \\
\text { to } \\
1.09\end{array}$ & $(-3.4$ to 4.3$)$ & $\begin{array}{l}(-3.1 \\
\text { to } \\
3.4)\end{array}$ & $\begin{array}{l}(-4.1 \\
\text { to } \\
3.7)\end{array}$ & $(-1.1$ to 6.7$)$ & $\begin{array}{l}(-1.1 \\
\text { to } \\
5.5)\end{array}$ & $\begin{array}{l}(-1.2 \\
\text { to } \\
6.6)\end{array}$ \\
\hline \multirow{2}{*}{$\begin{array}{l}\text { Hand } \\
\text { Temperature }\end{array}$} & -0.7 & 0.7 & 0.8 & 1.1 & 0.4 & -0.001 & 1.7 & -0.2 & -0.8 \\
\hline & $(-7.2$ to 5.8$)$ & $\begin{array}{l}(-4.9 \\
\text { to } \\
6.2)\end{array}$ & $\begin{array}{l}(-5.7 \\
\text { to } \\
7.4)\end{array}$ & $(-5.4$ to 7.6$)$ & $\begin{array}{l}(-5.1 \\
\text { to } \\
6.0)\end{array}$ & $\begin{array}{l}(-6.6 \\
\text { to } \\
6.5)\end{array}$ & $(-4.8$ to 8.2$)$ & $\begin{array}{l}(-5.8 \\
\text { to } \\
5.3)\end{array}$ & $\begin{array}{l}(-7.4 \\
\text { to } \\
5.7)\end{array}$ \\
\hline
\end{tabular}


Bold values denote statistical significance: $\left.{ }^{\star \star}\right) \mathrm{p}<0,01$ level; $\left(^{*}\right) \mathrm{p}<0.05$ level. Abbreviations; NA: Not applicable. SNAP: Sensory nerve action potential.

\section{Table 4. Subjetive measure.}

\begin{tabular}{|c|c|c|c|c|}
\hline $\mathrm{n}(\%)$ & $10 \mathrm{kHz}(\mathrm{n}=20)$ & $20 \mathrm{kHz}(\mathrm{n}=20)$ & Sham stimulation $(n=20)$ & $P$ value ${ }^{(a)(b)}$ \\
\hline Pain sensation & $0(0 \%)$ & $1(5 \%)$ & $0(0 \%)$ & $p=0.36$ \\
\hline Numbness & $8(40 \%)$ & $4(20 \%)$ & $3(15 \%)$ & $p=0.15$ \\
\hline Cold sensation & $8(40 \%)$ & $5(25 \%)$ & $0(0 \%)$ & $p=0.34$ \\
\hline Loss strength & $8(40 \%)$ & $8(40 \%)$ & $2(10 \%)$ & $p=0.057$ \\
\hline Heaviness sensation & $2(10 \%)$ & $5(25 \%)$ & $4(20 \%)$ & $p=0.37$ \\
\hline Tingle sensation & $5(25 \%)$ & $1(5 \%)$ & $0(0 \%)$ & $p=0.02$ \\
\hline Inflammation & $0(0 \%)$ & $0(0 \%)$ & $0(0 \%)$ & $N A$ \\
\hline Erythema & $0(0 \%)$ & $0(0 \%)$ & $0(0 \%)$ & $N A$ \\
\hline Hot sensation & $0(0 \%)$ & $0(0 \%)$ & $0(0 \%)$ & $N A$ \\
\hline Mean (SD) & $10 \mathrm{kHz}(\mathrm{n}=20)$ & $20 \mathrm{kHz}(\mathrm{n}=20)$ & Sham stimulation $(n=20)$ & $P$ value ${ }^{(c)}$ \\
\hline Pain intervention (0-10) & $4.95(1.9)$ & $3.45(1.9)$ & $3.2(1.8)$ & 0.19 \\
\hline Unpleasant (0-10) & $4.75(2.1)$ & $4.5(2.0)$ & $4.5(1.6)$ & 0.87 \\
\hline
\end{tabular}

Statistical test: ${ }^{(a)}$ Pearson's chi-squared test, ${ }^{(b)}$ Fisher's exact test, ${ }^{(c)}$ One-way analysis of variance (one-way ANOVA).

Table 5. Statistical analysis of blinding assessment.

\begin{tabular}{|llllll|}
\hline Participants Results & & & & \\
\hline Methods & Index & $p$-Value & $95 \%$ Confidence interval & Conclusion \\
\hline James & 0.44 & 0.098 & 0.37 to 0.51 & Blinded \\
\hline Bang-Active/ $2 \times 5$ & 0.8 & 0 & 0.72 to 0.87 & Unblinded \\
\hline Bang-Placebo/ $2 \times 5$ & -0.72 & 1 & -0.92 to- 0.53 & Opposite Guess* \\
\hline Assessor Results & & & & \\
\hline Methods & Index & $p$-Value & $95 \%$ Confidence interval & Conclusion \\
\hline James & 0.35 & $p<0.001$ & 0.24 to 0.45 & Unblinded \\
\hline Bang-Active/ 2x5 & 0.52 & $p<0.001$ & 0.36 to 0.69 & Unblinded \\
\hline Bang-Placebo/ $2 \times 5$ & 0.47 & $p<0.001$ & 0.25 to 0.70 & Unblinded \\
\hline
\end{tabular}

*Wishful thinking, participants tend to think they are allocated to the active group even inf not in reality. 


\section{Figures}

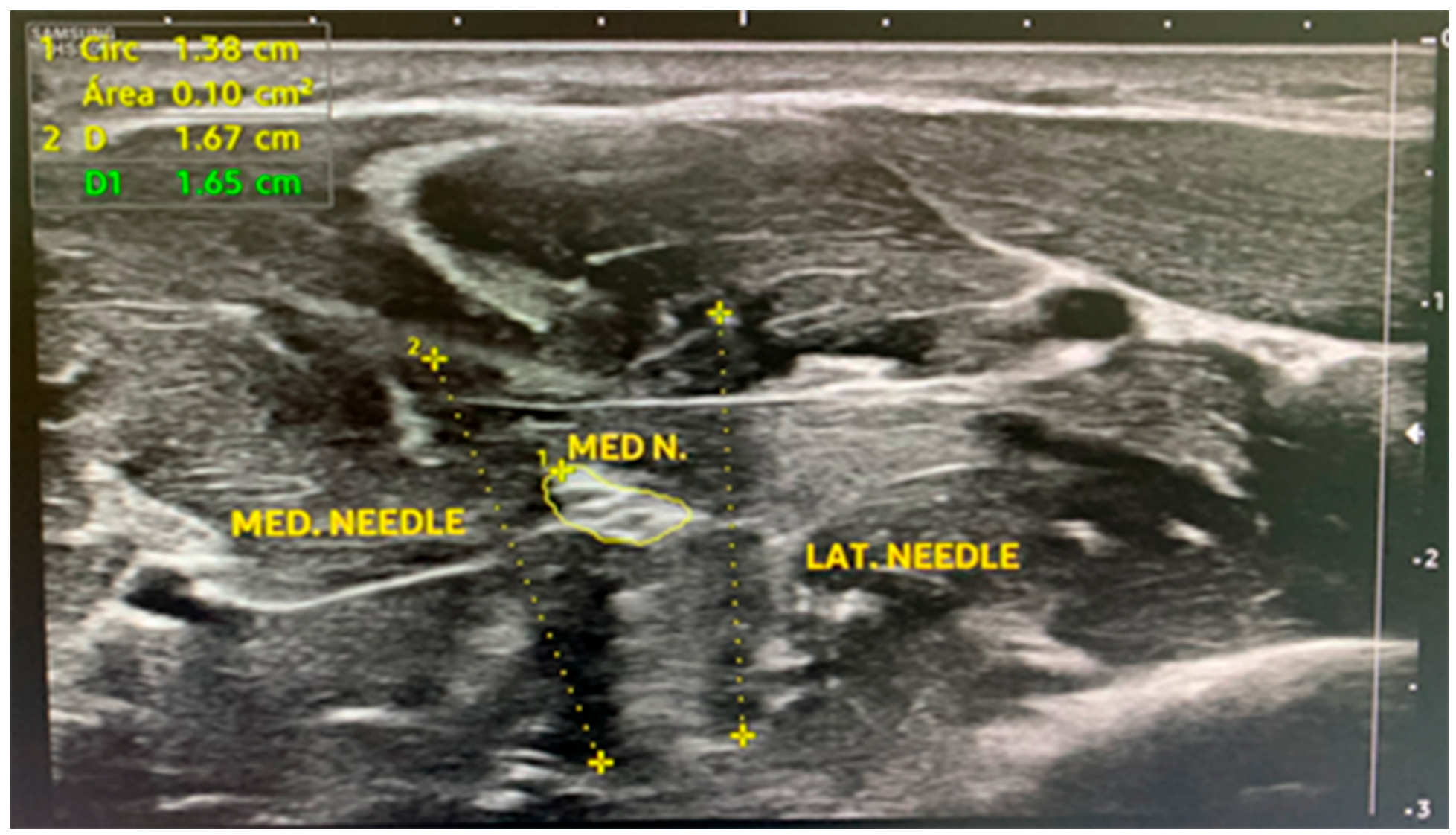

Figure 1

A short-axis approach to the median nerve with two acupuncture needles.

MED N.: Median Nerve; MED NEEDLE: Medial Needle; LAT NEEDLE: Lateral Needle. 

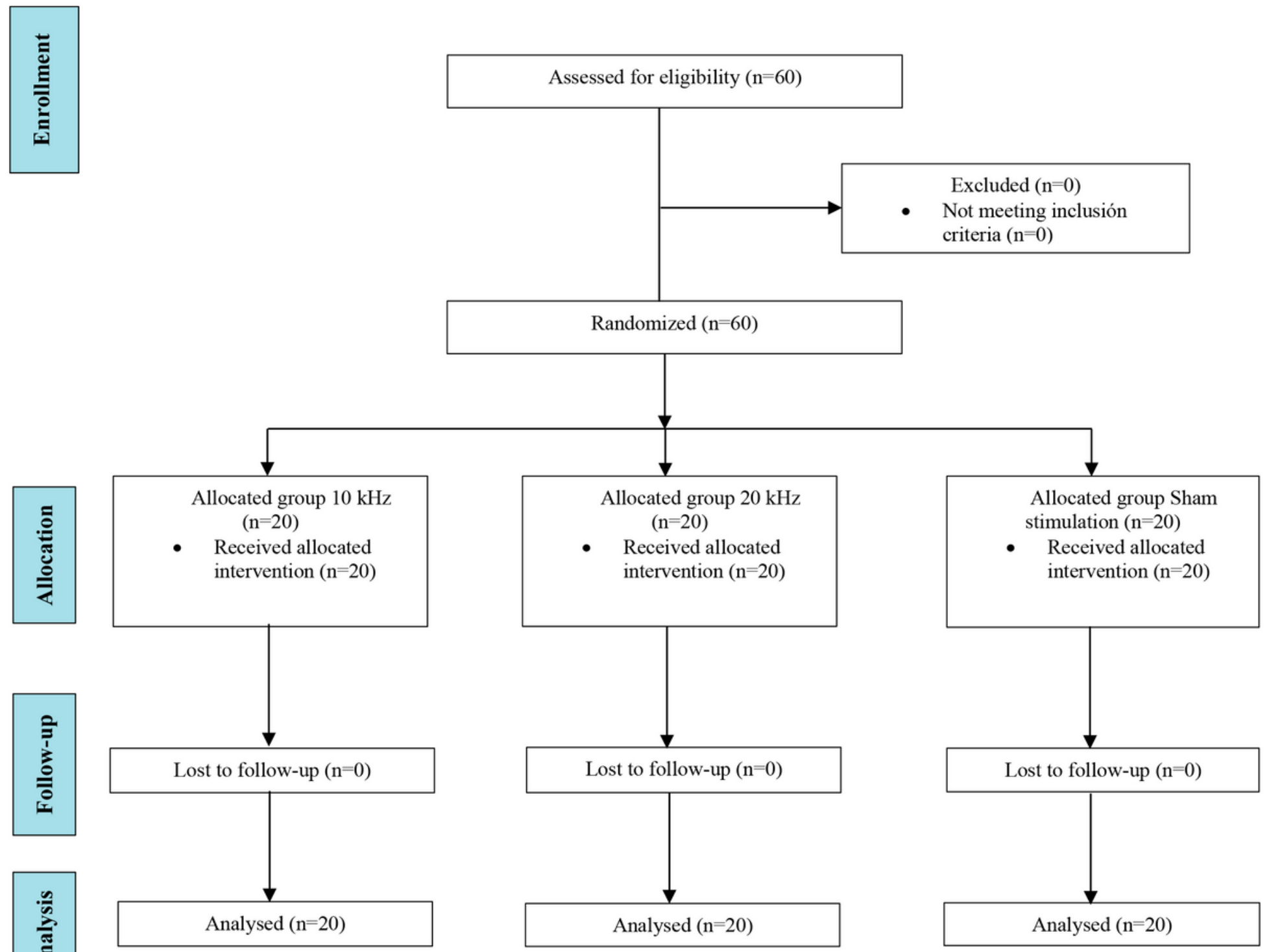

Figure 2

Flow diagram according to the CONSORT guidelines.

\section{Supplementary Files}

This is a list of supplementary files associated with this preprint. Click to download.

- Table6supplementarydata.docx 